\title{
ANALYSIS OF THE LOSSES OF PNEUMATIC DRIVEN CONCEPT VEHICLES
}

\author{
András GÁBORA ${ }^{1}$, Kristóf Balázs SIPOS², Gyula Dávid LOVADI ${ }^{3}$, Attila SZÁNTÓ ${ }^{4}$, Gusztáv \\ Áron SZÍKI ${ }^{5}$, Marian BORZAN ${ }^{6}$ \\ 1,2,3,4 University of Debrecen, Faculty of Engineering, Institute of Mechanical and Vehicle Engineering, De- \\ partment of Mechanical Engineering, Debrecen, Hungary \\ ${ }^{1}$ andrasgabora@eng.unideb.hu \\ ${ }^{2}$ siposk94@gmail.com \\ 3 lovadidavid@gmail.com \\ ${ }^{4}$ szanto.attila93@gmail.com \\ ${ }^{5}$ University of Debrecen, Faculty of Engineering Institute of Industrial Process Management, Department of \\ Basic Technical Studies, Debrecen, Hungary, szikig@eng.unideb.hu \\ ${ }^{6}$ Technical University of Cluj-Napoca, Faculty of Mechanical Engineering, Department of Production Engi- \\ neering, Cluj-Napoca, Romania, mborzan@yahoo.com
}

\begin{abstract}
The Faculty of Engineering of the University of Debrecen has more than ten-years of experience in developing vehicles with pneumatic drive. It is an increasing challenge for the developer teams to improve the performance of vehicles, with rules becoming increasingly strict year by year. Recently, a student team of the Faculty of Engineering began developing a telemetric system to support the other teams at our Faculty and improve the possibility of their successful racing in this way.
\end{abstract}

Keywords: pneumobile, pneumatics, loss, telemetry.

\section{Pneumobile competitions}

Since 2008, Aventics has organized annual international Pneumobile competitions [1]. Students of the University of Debrecen take part in these competitions each year. The competition consists of three different race events. In the skill event competitors have to complete different race circuits. In the long-distance event each team can use the same amount of energy to cover the longest distance, travelling at a minimum average speed of $15 \mathrm{~km} / \mathrm{h}$. The last event is the speed race event where a distance of $220 \mathrm{~m}$ has to be covered in the shortest possible time. For each event, the teams have a 10 litre tank filled with compressed air or nitrogen at a pressure of 100 bar. The teams have made a significant progress in all race events over the last ten years with the same competition rules. In the case of the distance race event, the average travelled distance was between 3 and $4 \mathrm{~km}$ in the early years of the competition, today the record is 12,990 m, held by Budapest University of Technology and Economics. Since the teams have the same amount of energy for the competition, the detailed and accurate knowledge of energy losses is essential for successful racing. To be able to determine these losses, an extended engineering knowledge is necessary due to the complex construction of pneumobiles.

\section{Description of the analysed pneumo- bile}

To be able to present the different types of energy loss it is important to give a general description of pneumobiles. The pneumobile analysed in this report was designed and constructed at the Faculty of Engineering of the University of 
Debrecen in the academic year 2015/16. For designing the above vehicle, we studied the most successful pneumobiles in the history of the competition. Based on the available statistics and data it can be concluded that the most successful pneumobiles are the PLC controlled ones with an alternating engine applying two steering wheels and a rearwheel drive [2]. Applying the above technical solutions the students have constructed the pneumobile in Figure 1. The most important technical characteristics of the pneumobile are summarized in Table 1.

Table 1. Characteristics of the pneumobile

\begin{tabular}{|l|c|}
\hline Height & $930 \mathrm{~mm}$ \\
\hline Width & $1100 \mathrm{~mm}$ \\
\hline Length & $2150 \mathrm{~mm}$ \\
\hline Wheelbase & $1350 \mathrm{~mm}$ \\
\hline Weight (without driver) & $100 \mathrm{~kg}$ \\
\hline Drive type & toothed rack \\
\hline
\end{tabular}

\section{Investigation of losses}

As mentioned earlier, the construction of pneumobiles is extremely complex, so a broad overview of the literature is needed to determine the losses. Conventional cars are dealt with in detail in the literature but the transposition of these measurement methods to a pneumobile is only possible to a certain degree. This is because the entire dynamics of the car is unique. Using a pneumatic circle, linear motion is produced using two cylinders driven by a specially designed toothed rack gear drive to provide rotation. Because of this design, it is necessary to examine separately what the parameters are that correspond to a conventional car. In addition to these parameters, it is necessary to examine the specific losses that the pneumatic circuit and the gear chain towing rack are vulnerable to.

\subsection{Conventional loss factors}

Although the drive solutions are unique due to the requirements of competition, the construction of the vehicle can be regarded as completely conventional in some respects. The vehicle presented in the study is a four-wheeled car with two front wheels providing steering. The braking system operates on a two-circuit mechanical principle generally. The unique feature of pneumobiles is that they usually have a wheel drive, in our case the left rear wheel is the driven wheel. As a result, the more advanced dynamical properties typical of general-purpose cars can be determined for the pneumobile. However, thanks to the pneumatic working medium, the resulting measurement will be extremely distinctive.

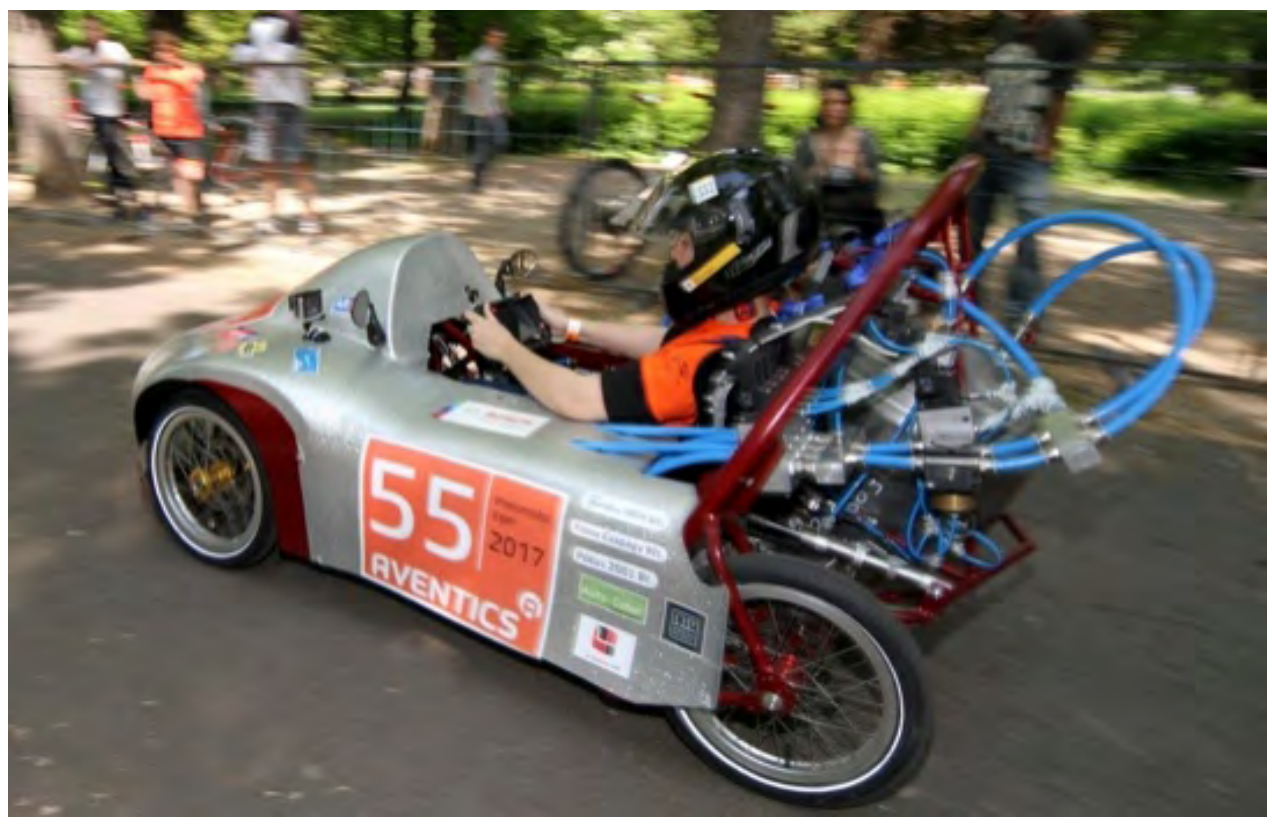

Figure 1. The analyzed pneumobile 


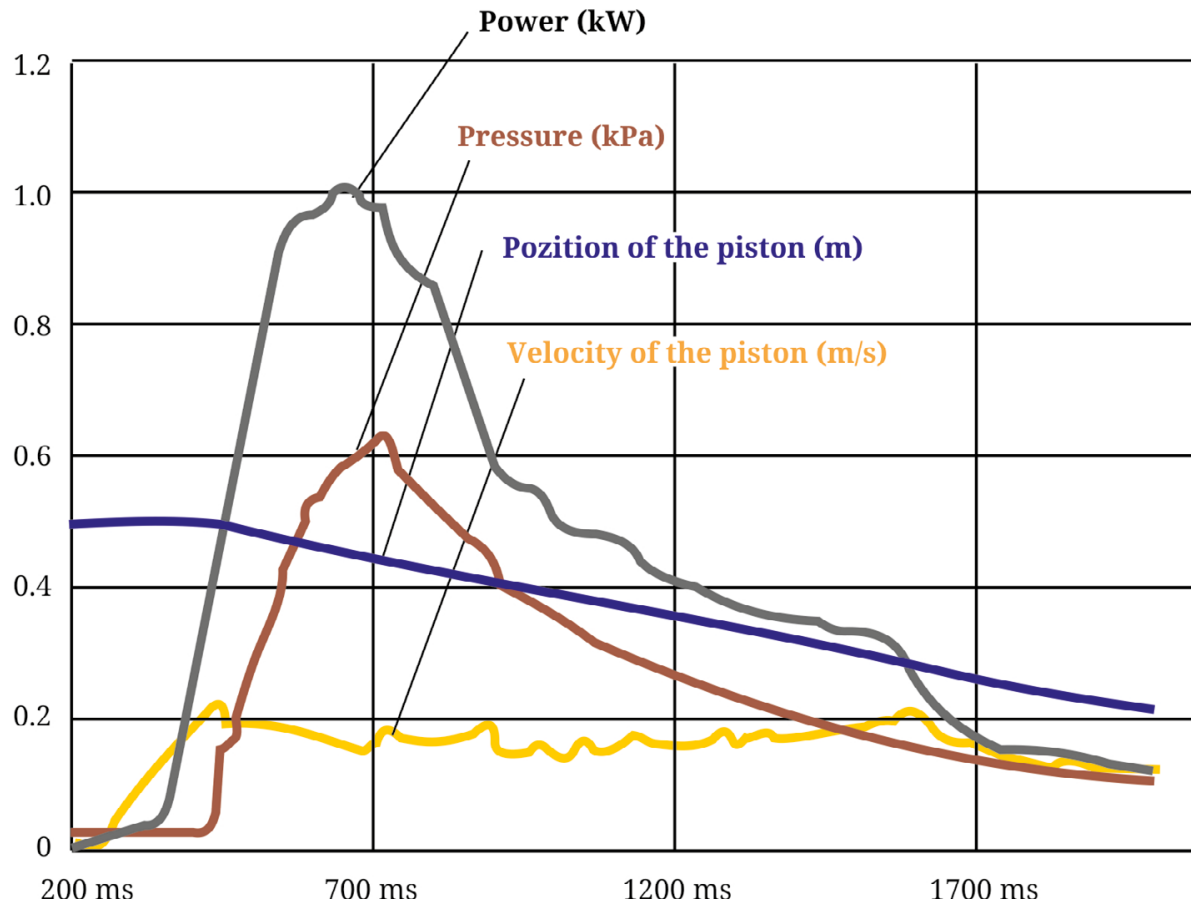

Figure 2. Performance Measurement Results [2]

It can be seen from the Figure 2. that the pressure drops at high piston speed and therefore the pneumatic capacity is also reduced. What can result in loss and therefore important for our investigations are: rolling resistance, air resistance, acceleration resistance [3]. These parameters can be significantly influenced by minor changes and their value can be determined under laboratory conditions [4].

\subsection{Toothed gear losses}

These gears are very widespread. The pneumobile we have produced has two different gears, the first transforms the linear movement of the toothed rack into a rotating motion and the second is in the gearbox. The connection between the two parts is provided by a chain drive. Gear and chain drives also have good efficiency when serviced regularly and properly. Since changing these drives is costly and complicated, we cannot deal with these losses in more detail.

\subsection{Pneumatic circuit losses}

Most of the literature on pneumatic losses defines a test method for flow over the sound velocity [5]. The flow rate in the cars pneumatic range depends on the actual race. This is easy to see, as it is used at a distance of over $10 \mathrm{~km}$ for a 10-liter, 100-bar airlift during a long-distance run, while in the speed race this amount is only sufficient for 220 meters. Due to this, we would like to examine the operation of pneumatic elements at several different flow parameters. Aventics and the organizers provide teams with access to a wide range of products. As a result, different product families can be compared by selecting teams that are the most appropriate for them. This provides great flexibility in the design of the pneumatic circuit. However, in order to accurately determine the pneumatic elements, a good telemetry system is required. This has partly been achieved by our students, however there is no way of continuous flow and temperature measurement.

\section{Conclusions}

We've gone around the bigger issues that can help reduce tiny losses so that we can compete even more successfully in future. We are currently working to determine these loss factors accurately and to determine their extent. This is a great challenge, since not only the transformation of the telemetry system is needed, but also the carrying out and elaboration of many laboratory measurements. 


\section{References}

[1] Pneumobil, Történet, 2018. (accessed 15 January, 2018)

http://www.pneumobil.hu/bemutatkozas/tortenet

[2] Zilahi K. L., Tóth X. E.: Sürített levegővel hajtott tanulmányautó mérő- és vezérlőrendszerének továbbfejlesztése. In: A XXII. Fiatal műszakiak tudományos ülésszak előadásai. Proceedings of the 21th international scientific conference of youngth engineers, Kolozsvár/Cluj, Kolozsvár,
Románia, Műszaki Tudományos Közlemények 7. (2017) 407-410.

https://eda.eme.ro/handle/10598/29831

[3] Zomotor Á.: Gépjármü menetdinamika. IdB Mérnöki Szakértői Iroda Budapest, 2003, 20-33.

[4] Gáspár P., Szabó Z., Bokor J.: Jármüdinamika és irányítás, Széchenyi Unitersity Press, Győr, 2014. 33-54.

[5] MSZ ISO 6358:1995: Pneumatikus energiaátvitel. Összenyomható munkaközeggel működő elemek. Áramlási jellemzők meghatározása. 